\title{
Article \\ The Impact of the COVID-19 Pandemic on the Development of Electromobility in Poland. The Perspective of Companies in the Transport-Shipping-Logistics Sector: A Case Study
}

\author{
Janusz Figura and Teresa Gądek-Hawlena *(D)
}

check for

updates

Citation: Figura, J.; Gądek-Hawlena,

T. The Impact of the COVID-19

Pandemic on the Development of

Electromobility in Poland. The

Perspective of Companies in the

Transport-Shipping-Logistics Sector:

A Case Study. Energies 2022, 15, 1461.

https://doi.org/10.3390/en15041461

Academic Editors: Tomasz Rokicki,

Piotr Bórawski and Sebastian Saniuk

Received: 23 December 2021

Accepted: 10 February 2022

Published: 16 February 2022

Publisher's Note: MDPI stays neutral with regard to jurisdictional claims in published maps and institutional affiliations.

Copyright: (c) 2022 by the authors. Licensee MDPI, Basel, Switzerland. This article is an open access article distributed under the terms and conditions of the Creative Commons Attribution (CC BY) license (https:/ / creativecommons.org/licenses/by/ $4.0 /)$.

\author{
Department of Transport, University of Economics, 1 Maja 50, 40-287 Katowice, Poland; \\ janusz.figura@ue.katowice.pl \\ * Correspondence: teresa.gadek-hawlena@ue.katowice.pl
}

\begin{abstract}
Negative processes occurring in the natural environment, under dynamic economy development, have become a factor for taking actions limiting destructive human activity. An important area in which initiatives are taken to improve the state of the natural environment is that of companies in the Transport-Shipping-Logistics Sector (TSL sector). The main objective of this article was to analyse the impact of the COVID-19 pandemic on the development of electromobility among companies in the Polish TSL sector, and identify factors that positively influenced or hindered its development during this time. For this purpose, qualitative and quantitative data analyses were carried out based on a literature review, statistical data, and direct research results. Descriptive statistics, chi-square test of concordance, and contingency coefficients were used to process the data. The results showed that the pandemic period did not affect the development of electromobility among TSL companies. Only a few companies own electric cars in Poland. Many of them did not plan to purchase this type of vehicle during the pandemic. The main factors influencing the decisions of entrepreneurs during the study period were the availability of charging infrastructure and electricity price uncertainty. The results of the study can be used by stakeholders of this sector in Poland.
\end{abstract}

Keywords: electromobility; companies in the Transport-Shipping-Logistics Sector; pandemic-COVID-19; development

\section{Introduction}

The redefinition of the energy model and the search for alternative energy sources are linked to problems that emerged in the second half of the 20th century in connection to the dynamic development of the Western world's economy. This development negatively affected the environment and the depletion of non-renewable natural resources, among other things. The great fuel crisis of the 1970s happened when emphasis was placed on renewable energy sources [1-3]. From that moment, a phase began in which electricity became the basis for the functioning of many societies. The result of these changes was an over $100 \%$ increase in electricity production compared with the 1960s [4]. Thus, electricity became the driving force of civilisation. The natural consequence is its use in transport [1-3]. Many years have passed since the first idea of using electricity in transport appeared [5,6]. During this time, enormous progress has been made in the field of electromobility. This has been driven by national governments, car manufacturers, the energy sector, researchers, and other stakeholders and organisations interested in electromobility [1-8]. These entities see the need to take action to address the ongoing processes associated with environmental degradation by transport $[9,10]$. The scope of these activities is evident in the increase in number of electric vehicles sold and the development of infrastructure necessary for their operation $[11,12]$. To illustrate the scale of the phenomenon, quantitative data may be quoted. In 2010, there were only roughly 17,000 electric cars on the roads worldwide. By 2019, this number increased to 7.2 million [12]. In 2020, about 3 million new electric 
cars were registered. In Europe, this amounted to 1.4 million new registrations. China was second with 1.2 million registrations, and the US registered 295,000 new electric cars [12]. According to Swedish consultancy EV-volumes.com, electric vehicles will account for $4.2 \%$ of all passenger car sales worldwide in 2020 [13].

Quantitative data shows [11,12] that the dynamic growth in the number of electric vehicles is largely within passenger vehicles and buses. This trend is a result of actions taken by many countries, found in policy documents which aim to reduce the negative environmental impact of transport [14-17]. In the European Union, passenger cars together with commercial vehicles are the source of $15 \%$ of greenhouse gas (GHG) emissions [18]. In turn, heavy duty vehicles are the source of $5 \%$ of GHG emissions. However, taking into account the continuous increase in the number of heavy duty vehicles and the environmental risks associated with this trend, the European Union is implementing specific policies and regulations aimed at the gradual decarbonisation of the vehicle fleet and the price reduction of zero-emission technologies. In 2019, the European Union adapted Regulation (EU) 2019/1242 [19], which sets $\mathrm{CO}_{2}$ emission standards for heavy duty vehicles up to 2030 Compared with the average $\mathrm{CO}_{2}$ emissions per kilometre for new vehicles sold between 1 July 2019 and 30 June 2020, new vehicles sold between 2025 and 2030 will have to emit on average $15 \%$ and $30 \%$ less $\mathrm{CO}_{2}$ respectively. Initially, the standards only apply to larger trucks, but the scope may be extended when these standards are reviewed in 2022 [20].

The assumptions may have a significant impact on the replacement of vehicle fleets of TSL companies. The replacement of vehicles by operators is determined by the development of electric trucks, charging infrastructure, and energy supply. At the same time, the pace and scale of the changes taking place in enterprises is influenced by the COVID-19 pandemic [21-24]. This impact was noted by Gersdorf T., Hensley R., and Hertzke P., Schaufuss P. [22], and can be analysed in the following areas:

- macroeconomic environment-the COVID-19 pandemic on one hand reduced the purchasing power of consumers and on the other contributed to a significant drop in oil prices and thus reduced the difference in maintenance cost of electric vehicles and combustion vehicles. This change may have affected the sales of electric vehicles [22,23],

- technology and infrastructure-some governments are investing in charging infrastructure as part of programmes to stimulate the economy even during the pandemic period [22,24],

- $\quad$ electric vehicle offers - the pandemic caused factories to close and stopped assembly lines around the world. As the automotive industry prepares to reopen, some are prioritising EV production either to meet expected strong demand or to meet regulatory requirements such as the European Union's stringent $\mathrm{CO}_{2}$ target [22,25-27],

- demand-in many countries, consumer demand for EVs has remained relatively stable during the crisis compared with demand for other vehicles. Globally, EV manufacturers offering online sales saw particularly high demand as the COVID-19 pandemic caused a lockdown $[22,28]$.

Taking into account the European Union guidelines on $\mathrm{CO}_{2}$ emission standards for heavy goods vehicles by 2030 [19], the rationale for the development of vehicles using alternative energy sources in road freight transport $[21,28,29]$, the size of Poland's medium and heavy commercial vehicle fleet in relation to other European Union countries [30], and the impact of the COVID-19 pandemic on enterprises [31], a significant need for research was recognised.

The aim of the study is to analyse the impact of the COVID-19 pandemic on the development of electromobility among companies in the TSL sector in Poland, and to identify factors that could positively influence or impede its development during the pandemic period. In addition, three sub-objectives were defined to:

- determine the potential for electric cars among the surveyed companies and to identify the demand for such vehicles, 
- identify factors which in the period of the COVID-19 pandemic had an impact on the potential and real need to purchase electric cars by companies in the TSL sector,

- to indicate the impact of the identified factors on the development of electromobility among companies from the TSL sector.

The structure of the article is as follows: Section 2 contains the literature review, Section 3 presents the aim and method of the research, Section 4 presents the results of the research, Section 5 contains the discussion, and Section 6 presents conclusions, limitations, and suggestions for future research.

\section{The COVID-19 Pandemic and the Development of Electromobility in Poland}

\subsection{Electromobility in a Sustainable Transport Concept}

Sustainability appears to be a modern concept that encompasses many ideas, but its meaning has evolved over time, with the most common connotation being something that lasts, is eternal, or that by its nature remains present, without consuming something externally harmful, and applying this to many areas of knowledge or society [32]. It is widely accepted "that sustainable development meets the needs of the present without compromising the ability of future generations to meet their own needs" [33]. The concept therefore identifies interrelated domains that constitute the dimensions of sustainable development: environment, economy, and society [34-36]. In this dimension, there is a growing interest worldwide in the phenomenon of sustainable development and its implications for the planning and operation processes of transport systems [37,38]. In practice, however, great difficulties arise in developing transport in the convention of integrated management (Table 1), that is, in the context of a broad understanding of sustainable transport.

Table 1. Dimensions of sustainable transport development.

\begin{tabular}{|c|c|c|}
\hline \multicolumn{3}{|c|}{ Sustainability } \\
\hline $\begin{array}{ll}\text { Social dimension: } \\
\text { - } & \text { mobility } \\
\text { - } & \text { availability } \\
\text { - } & \text { liquidity } \\
\text { - } & \text { security } \\
\text { - } & \text { social cohesion } \\
\text { - } & \text { system integrity } \\
& \text { transport }\end{array}$ & $\begin{array}{l}\text { The economic dimension: } \\
\text { - } \quad \text { competitiveness } \\
\text { in the sector } \\
\text { infrastructure (develop- } \\
\text { ment/modernisation/ } \\
\text { investment/carrying } \\
\text { capacity/quantity and } \\
\text { quality of } \\
\text { networkstransport) } \\
\text { intermodality }\end{array}$ & $\begin{array}{l}\text { Environmental dimension: } \\
\text { - } \quad \text { environmental friendliness } \\
\text { - } \quad \text { transport (minimising } \\
\text { environmental impacts) } \\
\text { - } \quad \text { prevention and eradication } \\
\text { - } \quad \text { transport implications } \\
\text { environmental risks }\end{array}$ \\
\hline
\end{tabular}

Source: [39].

Borys' [38,39] review of the definitions of sustainable transport showed both narrow and broad approaches to it in literature. At the same time, it is worth emphasising that the broad approach to the sustainable development of transport is considered the contemporary interpretation of the new development paradigm. Sustainable transport development means that the transport of people and goods will be carried out in a way that simultaneously takes into account environmental, social, and economic criteria (Table 1). It is, therefore, among other things, affordable, supports a growing economy, offers a wide choice of transport modes, reduces emissions and waste, minimises consumption of non-renewable resources and land use, and reduces noise pollution. This approach allows electromobility to fit into the concept of sustainable development. As with the concept of sustainability, there is no single accepted definition of electromobility [40,41]. According to Caternì [40,42], electromobility is one of the most studied topics in transport and is a very complex issue, as it cannot be interpreted within a single theoretical structure. An important factor in the discussion of electromobility is that an electric vehicle cannot be 
implemented by the automotive industry without the parallel development of charging infrastructure, service networks, technical approval processes, and tax and legal incentive mechanisms [42-45]. In the most general terms, electromobility encompasses issues related to electric vehicles, both in individual transport (cars and motorbikes) and mass transport (buses, trolleybuses, trams, trains). Electromobility also includes all technologies related to the production of e-vehicles, energy management, and charging infrastructure, as well as modern transport strategies $[8,46]$.

An area that still requires analysis is the issue of electromobility in road freight transport. Many publications in this area refer to the problems of alternative power sources [47-49] and, in this context, the issues related to the electricity sector and its impact on the environment [50-53] concerning decarbonisation are very important.

\subsection{Impact of COVID-19 on the Evolution of the Electric Vehicle Market}

One important aspect related to the development of electromobility is the change in the number of electric vehicles being purchased. An electric vehicle is defined as a vehicle that is powered by at least one electric motor. Electric vehicles also include hybrid cars-HEVs, PHEVs, and fuel cell vehicles-FCHEVs $[18,45]$. While the demand for electric buses and passenger vehicles is increasing both in Poland and in most European Union countries [30], the share of heavy duty vehicles powered by alternative energy sources is low (Figure 1).

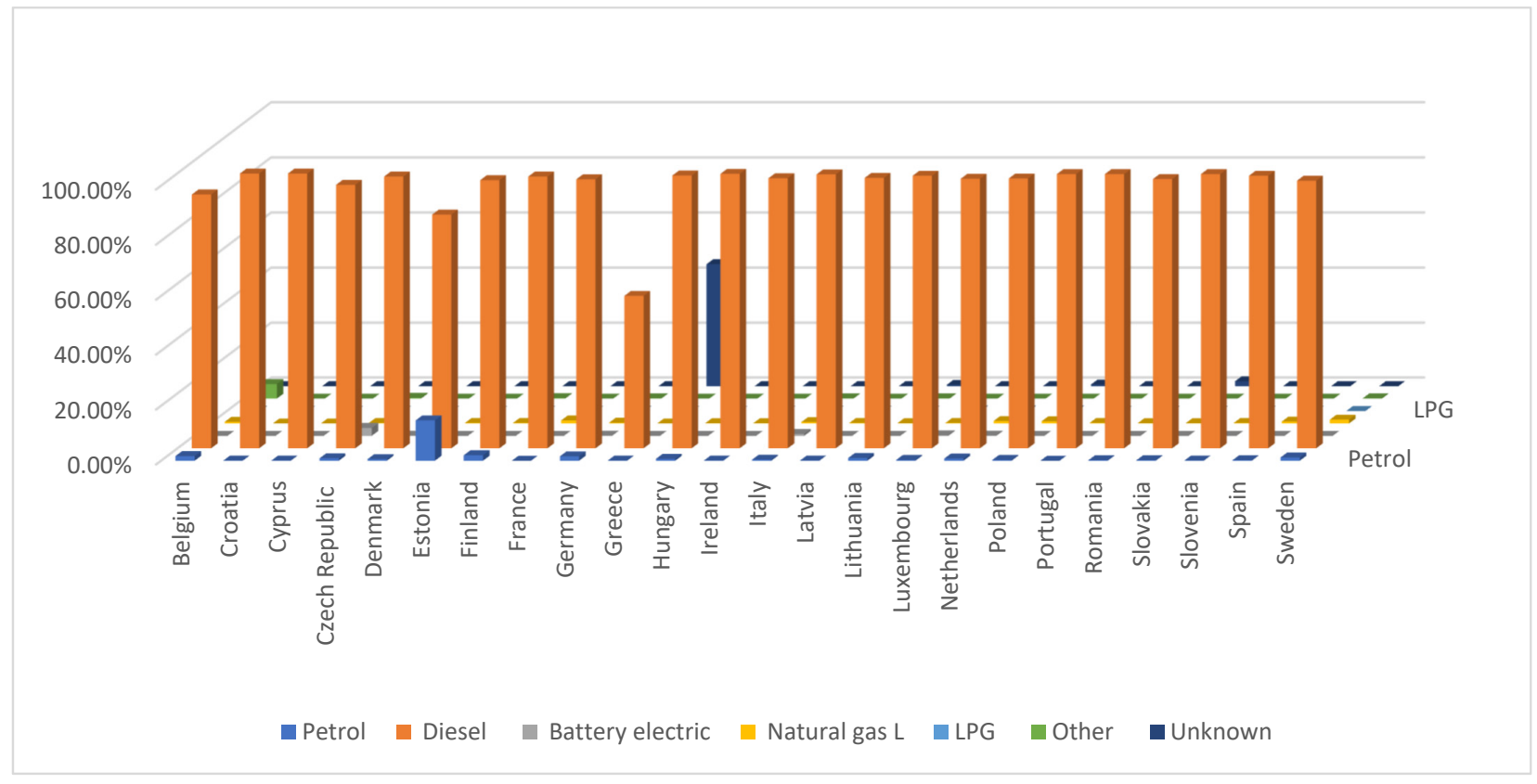

Figure 1. Medium and heavy commercial vehicles by fuel type in EU in 2020 [30]. (no data from some UE countries).

Analysing the percentage share of individual types of vehicles by fuel type in European Union countries, it may be observed that vehicles with combustion engines dominate, accounting for more than $90 \%$ of all medium and heavy vehicles (Figure 1). There is a small share of BEV in countries such as the Czech Republic- $2.9 \%$, Latvia- $0.7 \%$, Luxembourg- $0.2 \%$, and Denmark, Germany, and the Netherlands- $0.1 \%$. Plug-in hybrid and hybrid electronic vehicles are not found among medium and heavy vehicles. As indicated by H. Quak et al. [54], the low share of electric vehicles among HGVs may be affected by several factors:

- the specific type of vehicle in a given model has a strong influence on the technolo-gical performance and reliability of the vehicle,

- the lack of and high cost of effective manufacturer support in the event of repair needs, 
- the development of ICT support is indispensable for the further integration of electric HGVs into daily business of transport companies,

- limited production and availability, especially of heavy electric freight vehicles,

- the need for new investment and adaptation of existing infrastructure.

Electromobility development activities are of a different nature and scope in different countries. At the same time, many studies point to the role played by authorities at various levels in this field [16,55].

When analysing the years 2019-2020, when the world was facing the COVID-19 pandemic, no significant contribution to the growth of vehicles powered by alternative power sources was observed (Figure 2).

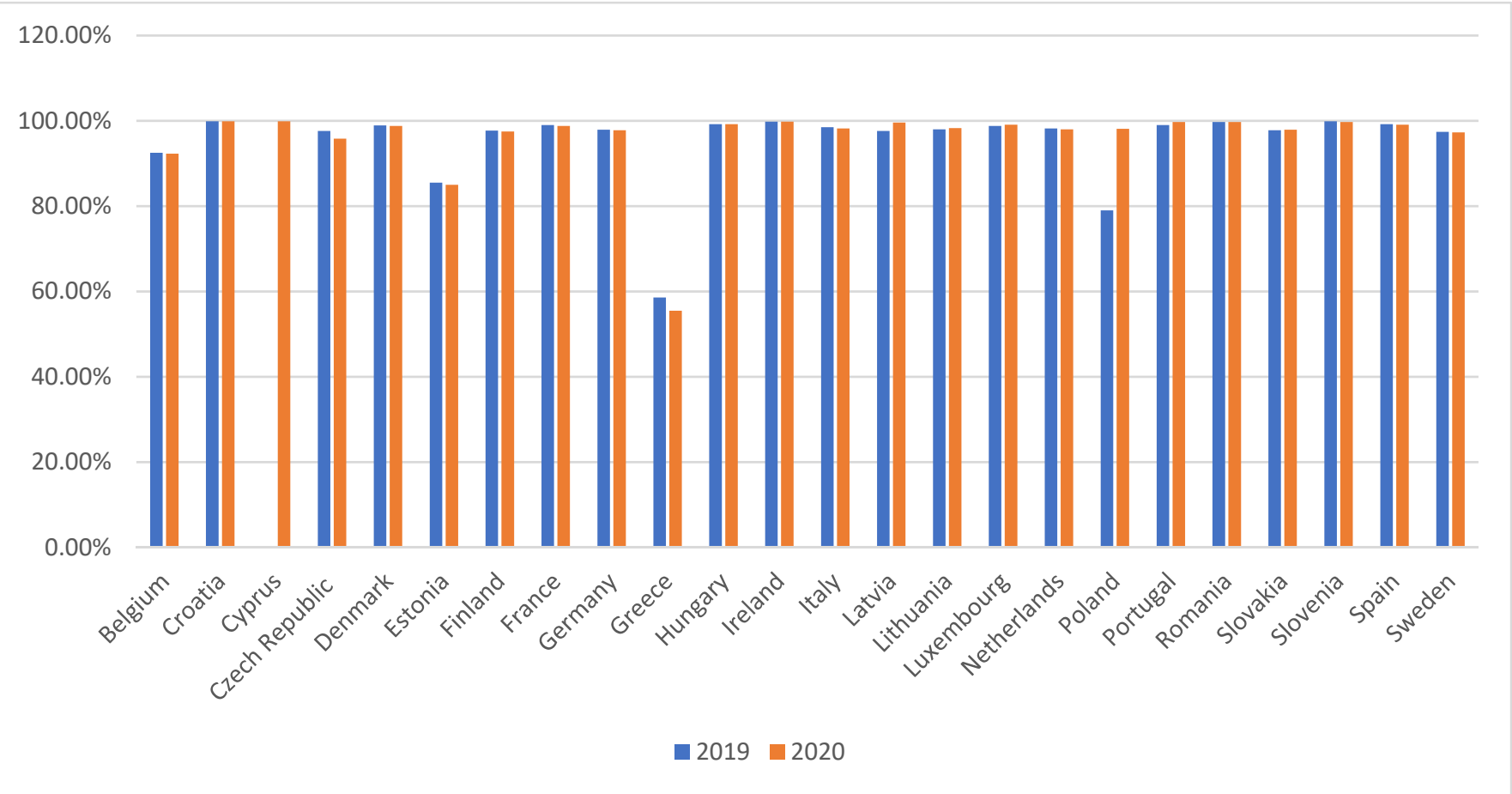

Figure 2. Medium and heavy duty diesel commercial vehicles in the EU [30,56]. (no data from some EU countries.).

Despite efforts to develop electromobility in road transport, there has been no significant decline in the share of diesel vehicles in individual EU countries. In most cases, the decline has been around $0.1 \%$. At the same time, there are countries, including Poland, which recorded an increase in the share of diesel-powered vehicles in the total number of medium and heavy commercial vehicles during the COVID-19 pandemic. Apart from Poland, an increase was recorded in such countries as: Latvia, Lithuania, Luxembourg, Slovakia, Slovenia, and Spain. However, these countries, compared with Poland, have a much smaller number of medium and heavy vehicles. Thus, in 2020 those countries had medium and heavy commercial vehicles in the following numbers: Latvia-22,513 vehicles, Lithuania69,780, Luxembourg-13,784, Slovakia-78,959, Slovenia-37,674, Spain-614,147, and Poland — as many as 1,184,677.

Taking into account the total number of cars analysed by fuel type in Poland, electric cars in 2020 will represent only $0.05 \%$ of all trucks (Figure 3). At the same time, during the COVID-19 pandemic period, i.e., 2019-2020, a slight increase in their number was observed in each of the vehicle groups.

In 2020, the number of heavy electric vehicles reached 1729 units, an increase of almost $68 \%$ compared with 2016. Considering the period of the COVID-19 pandemic, there was no downward trend in the total number of vehicles (electric cars and diesel cars). Thus, 
the COVID-19 pandemic did not affect the purchase of alternative-powered HGVs, but this may be due to insufficient knowledge about electromobility or insufficient charging infrastructure, among other factors. A positive aspect in this area is the research on the possibility of using vans and trucks with TSL companies $[13,57]$.

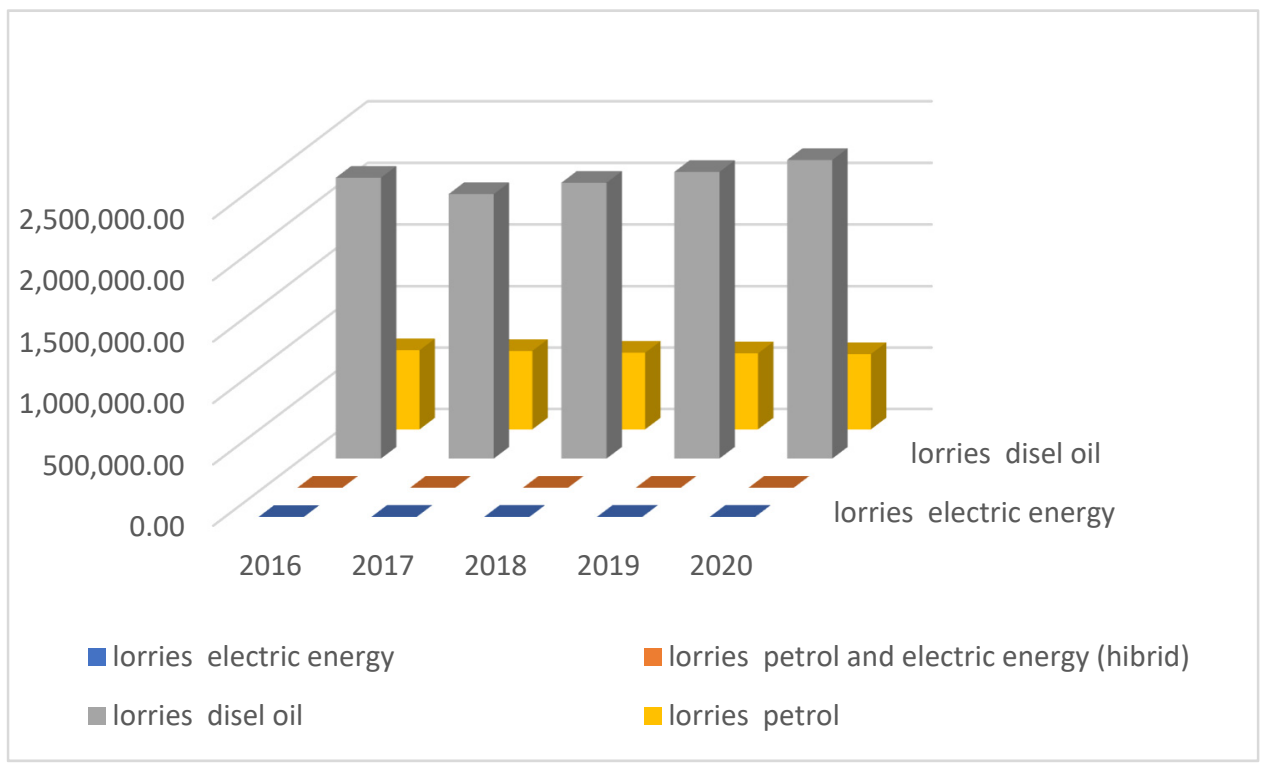

Figure 3. Breakdown of vehicles by fuel used in Poland [58-61].

According to Gajewski J., Paprocki W., and Pieriegud J. [7], the electrification of the transport sector in Poland in the period before the COVID-19 pandemic was slower than in other European markets. This applied both to the number of electric cars registered and to system solutions supporting the development of electromobility. Therefore, the authors of the study indicate that one million electric vehicles on the roads in 2025, which is the strategic goal of the Polish Electromobility Development Programme, is practically unattainable. Nevertheless, the legislative, economic, and technological changes taking place in Poland make it possible to assume that the sales of EVs will continue to grow dynamically. At the same time, these changes are related to transformations in the energy sector, which in Poland require changes due to the use of coal for energy production [62].

\subsection{The Impact of the COVID-19 Pandemic on the Development of Charging Infrastructure}

The development of charging infrastructure is influenced by state actions. Poland, through the Strategy for Responsible Development, as well as detailed plans for the development of electric transport, including the development of charging infrastructure [63], is trying to catch up with countries that impose a pace of change in the electromobility sector [7]. In 2017, the Plan for Electromobility Development in Poland [14] was developed, the main objective of which was to create conditions for the development of this sector in the country. It assumed that building charging infrastructure would be an additional pro-demand factor. The network will be fully prepared to supply 1 million electric vehicles, and those vehicles will be stabilisers of the power system. The pandemic had no impact on the expansion of charging infrastructure between 2019 and 2021, and an increase in the availability of charging stations during this period did occur [64].

As can be seen from the EAFO quantitative data (Figure 4), there has been a very large increase in the number of charging points in Poland. In the case of fast charging points, taking 2016 as the base year, in 2019 the increase was 182\%, and in 2020 more than 300\%. According to the estimates of the PSPA Research and Analysis Centre [65], the increase in the number of widely available charging points for electric cars should definitely accelerate. This may be facilitated by the 'e-tariff' in force from 1 April 2021 [66], which will make i66t possible to reduce the fixed costs of operating chargers, and by the planned introduction of 
a system for subsidising the infrastructure [65]. On the other hand, the cost of creating new stations should be taken into account. In 2018, the cost of creating a new charging station was around 40 thousand PLN, and in the case of fast charging stations, the cost rose to 100-190 thousand PLN. At the same time, the rising level of inflation in Poland has already increased these costs significantly. Access to public stations is free of charge and is usually used to promote a particular company or the idea of electromobility itself. The Ministry of Energy has declared that, according to their estimates, the profitability of a charging station can be achieved when sales reach 32.85 MWh for an ordinary station and 452.6 MWh for a fast charging station. However, a large margin should be added to these figures as they are calculated based on an energy price that is no longer used on the market [67].

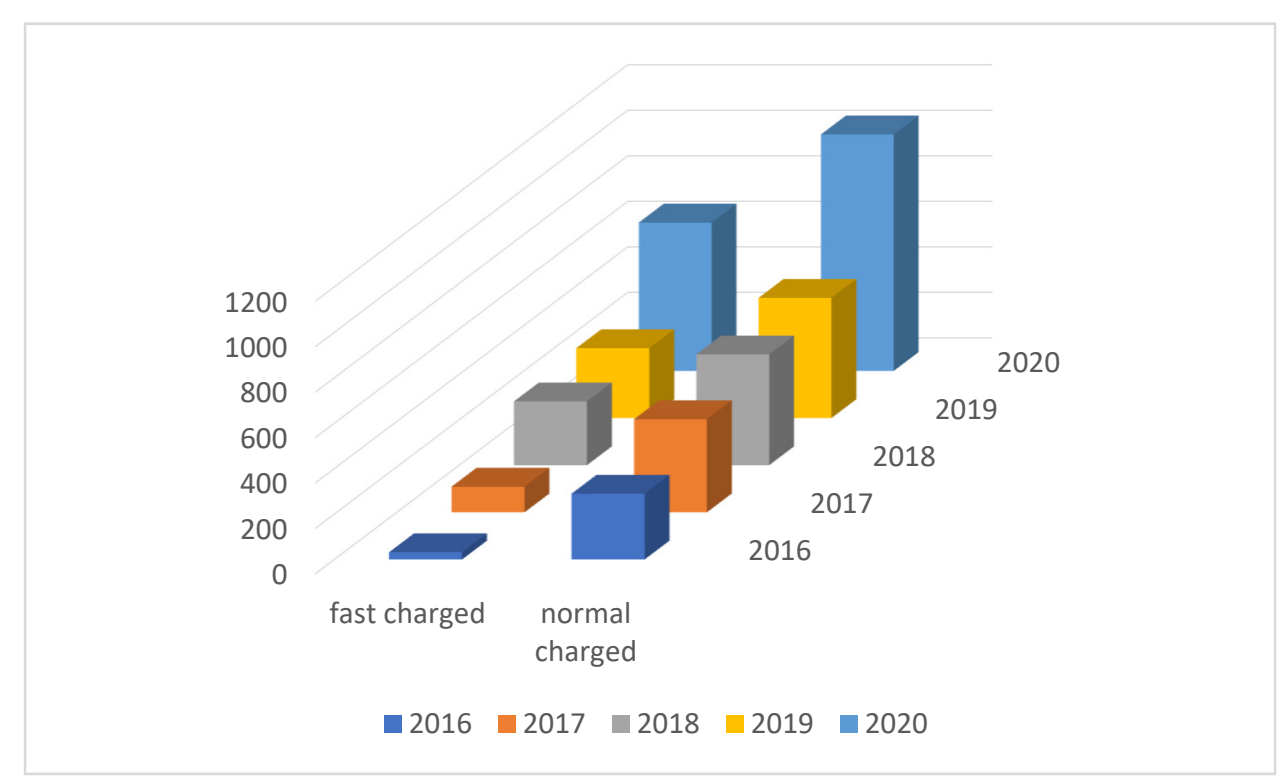

Figure 4. The total number of normal and high-power public recharging points [18].

At the same time, Poland is not a country with a large number of charging points (Figure 5). 


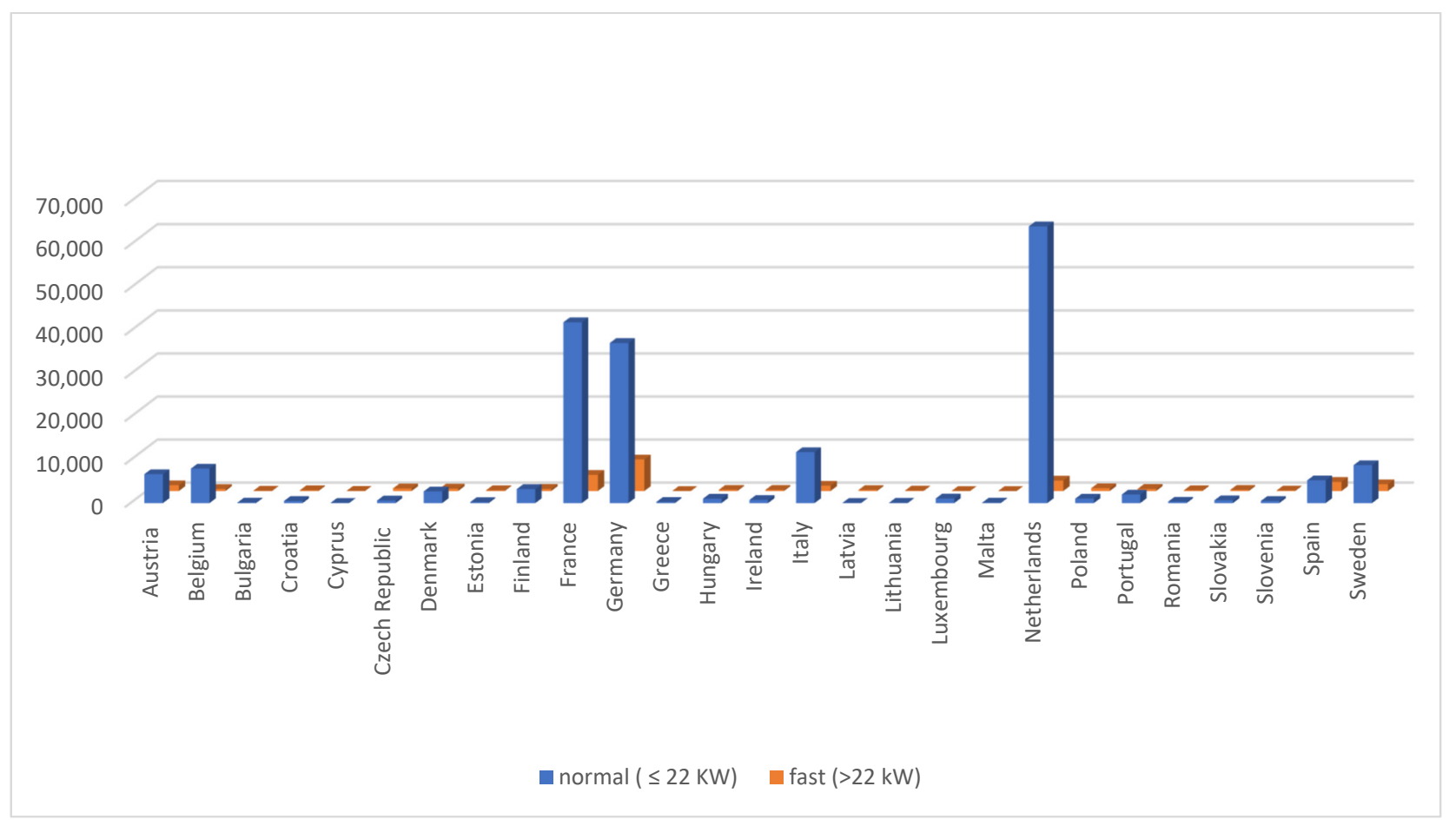

Figure 5. Normal and fast charging points in European Union (2020) [67].

Among European Union countries, the highest number of charging points is found in the Netherlands $(66,665)$, followed by France $(45,751)$, Germany $(44,538)$, Italy $(13,073)$, and Sweden $(10,370)$. However, these countries have the highest number of fast charging points. These countries also have the highest number of fast charging points (Germany7325, France-3751, the Netherlands-2429). This situation may have a negative impact on the replacement of the vehicle fleet among companies in the TSL sector. Taking into account the trucks used in the TSL sector and the number of fast charging points in the entire European Union (25,000 public chargers), it can be concluded that one of the main problems in the development of electromobility is not the COVID-19 pandemic, but the lack of available charging infrastructure. However, to enable the right direction for the development of electric vehicle charging infrastructure, it is necessary to take into account their establishment in locations with high charging potential, identified by different criteria such as demand density or length of travel $[68,69]$.

\section{The COVID-19 Pandemic and the Development of Electromobility in the TSL}

\subsection{Materials and Methods}

The survey method was used in order to answer the research questions. Surveys play an important role in research processes by creating formal basis and translating theoretical assumptions into empirical procedure language. These methods are of an analytical nature and are widely used in social sciences, making it possible to identify the designated opinions of people (respondents) in relation to specific socio-economic phenomena occurring in the organisation [70].

The survey approach used in the study aimed to link the impact of the COVID-19 pandemic on the development of electromobility among TSL companies. The survey questions were structured to capture two aspects. The first was the issue of the purchase of electric vehicles by companies in the TSL sector during the COVID-19 pandemic, taking into account the company's reach and period of operation and to identify factors that, in addition to the coronavirus, influenced vehicle purchase decisions.

The questionnaire was divided into three parts. In the first part, in order to define the respondent's profile, five variables were presented: the organisational and legal form of the 
company, the area of operation, the range of operation, the period of operation, and the number of employees. The second part of the survey questionnaire identified companies with electric vehicles and their preferences regarding the purchase of this type of vehicle since the beginning of the COVID-19 pandemic. The third part of the sheet concerned the assessment of the impact of the COVID-19 pandemic on the development of electromobility among companies in the TSL sector. In this part of the worksheet, a Likert-type scale was used [71], where 1 meant no impact and 5 meant a very strong impact. Prior to the survey, the questionnaire was tested by people who are scientifically involved in electromobility and representatives of TSL sector companies. This test was to ensure the relevance of the questions and to assess the acceptability of the wording that was used, as well as the understanding of the questions. The online survey was created using Microsoft Forms software. It was then distributed to companies in the TSL sector. The data collection period spanned three months, from July to September 2021. The survey was a pilot study and represents the initial stage of research related to the development of electromobility in Poland among companies in the TSL sector. The results constitute a case study. In order to analyse the obtained results, structure indicators and the $\chi^{2}$ test of independence and the contingency coefficient $\varphi[72]$ were used.

\subsection{Profile of Study Participants}

The survey involved 71 respondents whose answers were checked and verified for completeness as well as correctness and reliability of information. This was to eliminate irregularities in the completed questionnaires. The first part of the survey questionnaire was designed to record the basic variables of the participating companies (Table 2).

Table 2. Characteristics of respondents.

\begin{tabular}{ccc}
\hline Demographic Characteristics & Participation & Percentage (\%) \\
\hline & $\begin{array}{c}\text { The legal and organisational } \\
\text { form of the company }\end{array}$ & \\
corporation & 29 & 40.85 \\
partnership & 25 & 35.21 \\
sole proprietorship & 17 & 23.94 \\
logistics company & Scope of action & 33.80 \\
transport and shipping & 24 & 36.62 \\
company & 26 & 29.58 \\
transport company & 21 & 46.48 \\
national & Range of action & 53.52 \\
international & 33 & 45.07 \\
up to 10 years & 38 & 54.93 \\
over 10 years & 32 & \\
& 39 & 29.58 \\
up to 10 & 21 & 25.35 \\
11 to 49 & 18 & 16.90 \\
from 50 to 249 & 12 & 28.17 \\
above 249 & 20 &
\end{tabular}

Among the researched entities, taking into account their organisational and legal form, there were capital companies, including mainly limited-liability companies. The choice of this form of business results from the relatively low costs of establishment in comparison with other types of capital companies. In terms of other variables (Table 2), the share of respondents was comparable, except for the number of employees variable. The analysis of the number of employees was dominated by companies employing up to 10 people $(29.58 \%)$. Among the companies in the TSL sector, entities employing up to 10 people constitute a significant group of enterprises. At the same time, the second 
most numerous group participating in the survey were enterprises employing more than 249 persons $(28.17 \%)$. This group of enterprises is represented by the smallest number of entities in the TSL sector in Poland.

\section{Test Results}

\subsection{Impact of the COVID-19 Pandemic on the Purchase of Electric Vehicles}

The first issue raised in the survey questionnaire was the question of companies' ownership of electric vehicles and their willingness to purchase them since the beginning of the COVID-19 pandemic. The reconnaissance showed that only $14.08 \%$ of respondents indicated that they have electric vehicles in their fleet. These companies primarily own cars and vans. Only two of the companies surveyed indicated that they have electric trucks. This group consisted primarily of logistics companies with international operations, employing more than 249 people and operating for more than 10 years. However, in the group of companies employing up to 10 people, none had an electric vehicle. Only two of the surveyed companies indicated that they have electric trucks and these were companies operating in transport and forwarding, with international reach, for more than 10 years. Furthermore, only 16 companies planned to purchase an electric vehicle in 2020 . These were also primarily logistic companies with more than 249 employees. This means that the purchase of electric vehicles is considered primarily by large entities, which comes from the scale of their business activity and financial capabilities. The results of the survey are consistent with other studies, which indicate that as many as $51 \%$ will not electrify their fleet [1]. As Polish transport companies have an almost 30\% share in international road transport in the EU [20], it was checked whether the company's range of operation has an influence on the purchase of an electric vehicle. For this purpose, the study was carried out using the $\chi$ test $^{2}$. The assumption was made, hypothesis H0, that there is a relationship between the range of transport operations and the purchase of an electric vehicle, and an alternative hypothesis was made, H1, in which it was assumed that there is no relationship between the purchase of an electric vehicle and the range of operation of the company. The test yielded a result of $\chi^{2}=0.1114$, with $\alpha=0.05$. The contingency coefficient $\varphi=0.040$ was then determined, its magnitude indicating a very weak relationship between the variables. Hypothesis H1 was rejected (CHI_TEST $>\alpha$ ), i.e., the relationship between the two characteristics was not statistically significant. Therefore, it can be concluded that, in this case, it was not the COVID-19 pandemic that directly influenced the lack of demand for electric vehicles. Since the COVID-19 pandemic has an impact on the health of many operators, the relationship between the willingness of companies in the TSL sector to purchase electric vehicles and the period of operation was examined. An assumption was made, hypothesis $\mathrm{H} 0$, that there is a relationship between the operational period of the company and the purchase of an electric vehicle, and an alternative hypothesis was made, H1, in which it was assumed that there is no relationship between the purchase of an electric vehicle and the operational range of the company. The test yielded a result of $\chi^{2}=0.2068$, at $\alpha=0.05$. Hypothesis H1 was rejected (CHI_TEST $>\alpha$ ), i.e., the relationship between the two characteristics is not statistically significant. Therefore, it can be concluded that in this case, it was not the COVID-19 pandemic that directly influenced the purchase of electric vehicles in the group of surveyed entities, but the limited availability of charging infrastructure. Next, the contingency coefficient $\varphi=0.054$ was determined; its magnitude indicated a very weak relationship between the variables.

\subsection{Influence of Selected Factors on the Purchase of an Electric Vehicle by Companies in the TSL Sector}

Three groups of factors may have influenced the purchase of electric vehicles by TSL operators, during the COVID-19 pandemic, based on literature recognitions [22,28]. These are economic factors, which include the uncertain economic situation of the country and the condition of the surveyed companies. Another group of factors influencing the development of electromobility include state actions, including the system of incentives and the stability of electricity prices. An important group of factors for companies in the 
TSL sector includes the accessibility to infrastructure. In this aspect, analyses are presented based on the obtained research results. The first factor examined was the economic situation of the country (Figure 6).

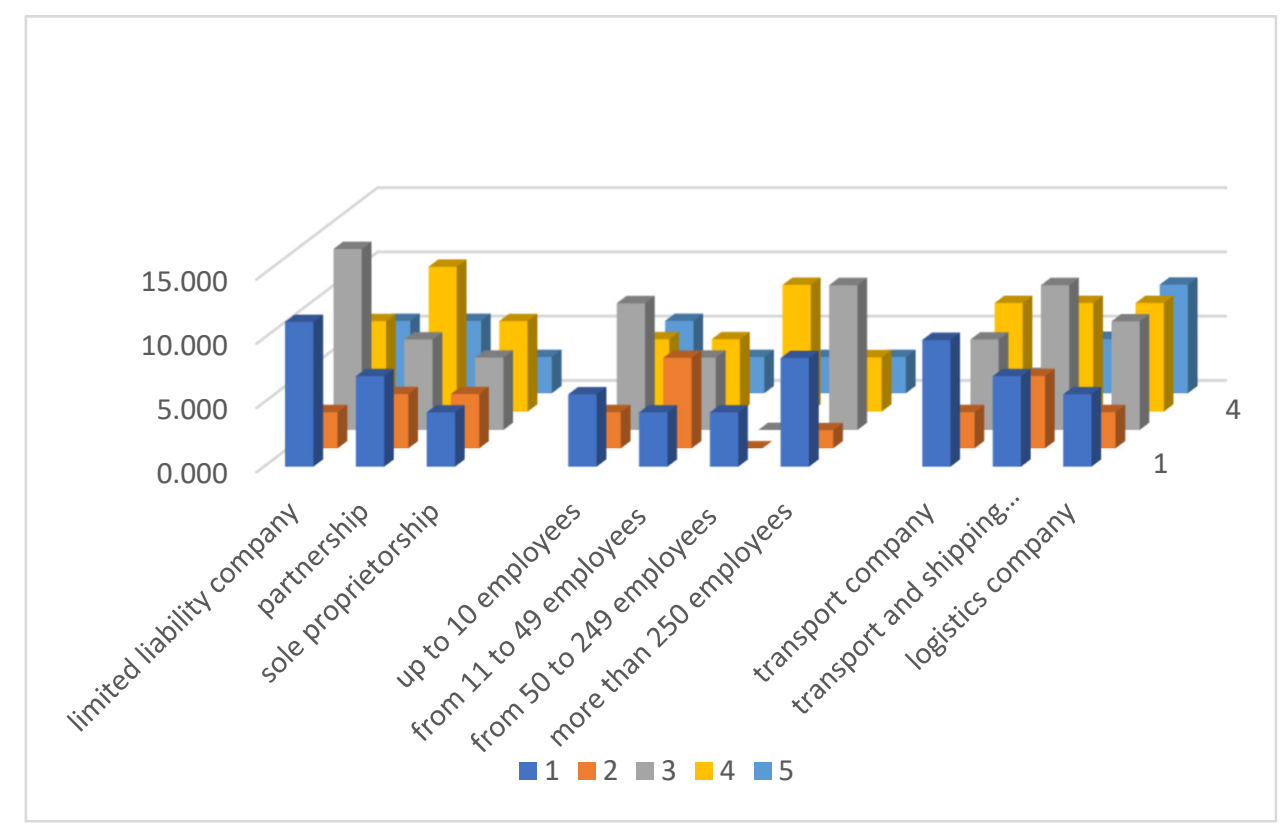

Figure 6. National economic situation and demand for electric vehicles—criteria organizational and legal form, employment structure, and scope of activity.

The impact of the country's economic situation on the demand for electric vehicles in the group of entities studied should be considered; taking into account the organisational structure of enterprises, it had the strongest impact on partnerships with enterprises divided by employment structure into companies employing between 50 and 249 people and those providing logistics services. In contrast, the weakest interest in purchasing vehicles during the COVID-19 pandemic was characterised by incorporated companies, with more than 250 employees and providing transport services. It is worth noting that the coronavirus pandemic has fundamentally changed the Polish TSL market; on one hand, it contributed to the dynamic growth of e-commerce, creating new development opportunities, and on the other hand it forced the enterprises to adapt to the changing reality. The report of the Polish Economic Institute shows that companies in the TSL sector have the highest economic situation index of all branches. At the same time, the lack of interest in electric vehicles is not connected with investment expenditures. The TSL sector is one in which more than half of the enterprises incurred investment expenditures. In more than every fifth company investment, expenditures increased. The increase in investment is most often associated with TSL companies (27\%) as well as large and small enterprises (25\% each) and medium-sized enterprises (24\%) [73].

Since charging infrastructure is associated with EV ownership, whether the availability of fast charging infrastructure especially along motorways and expressways influenced the purchase of an electric car during the coronavirus period was investigated (Figure 7). As can be seen, the companies surveyed indicated that during the COVID-19 pandemic period, the availability of fast charging points had an impact on the demand for electric vehicles. Taking into account the organisational and legal form, the highest number of indications for the strong impact related to the availability of fast charging points was indicated by capital companies and partnerships, while in the case of sole proprietorships, the availability of fast charging points was not so important. On the other hand, taking into account the number of employees, it should be stated that for each of the groups of enterprises the availability of fast charging points was significant, especially among enterprises employing 
11-49 employees. Despite the fact that transport companies should mainly care about the availability of fast charging points, research shows that these companies indicated a weaker influence of the location of fast charging points compared with transport and forwarding or logistics companies. This research corresponds to the research conducted among Polish drivers, who indicate that the interest in electric vehicles is affected by the lack of sufficiently developed public charging infrastructure [74].

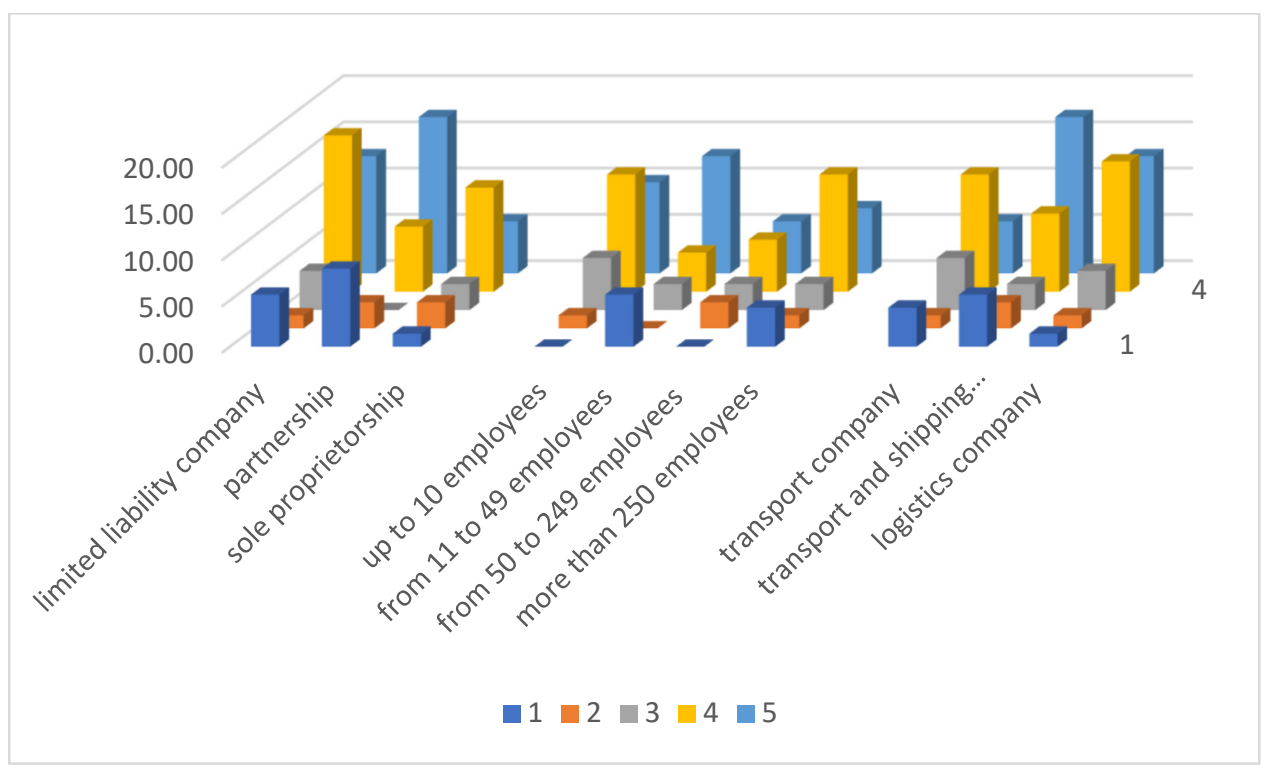

Figure 7. Availability of fast charging points at motorways and expressways and demand for electric vehicles_criteria organisational and legal form, employment structure, scope of activity.

The last factor presented in the study - uncertainty related to energy access - should be considered as significantly affecting the demand for electric vehicles in the group of entities studied (Figure 8). A comparable impact of this factor is characteristic of capital companies and sole traders. However, among sole traders, there was no reply about the total lack of influence of uncertainty in energy prices on the demand for electric vehicles. Uncertainty related to electricity prices is particularly important for enterprises with up to 10 employees. In this group of enterprises, none of the respondents, as in the case of sole proprietorships, marked answer 1 -no impact. On the other hand, taking into account the scope of activity of the company, it can be seen that price issues are important for transport, transport-forwarding, and logistics companies. Although the cost of driving an electric vehicle is not high (for the MAN e-TGE 136KM/35.8KWh car, Greenway operator, tariff: Energy Standard (charging with power from 70 to $140 \mathrm{KW}$ )), the cost of driving $100 \mathrm{~km}$ is 74.33 PLN. The respondents' indications may have been influenced in the period under study by government actions related to fuel increases and the dispute between Poland and the Czech Republic over the Turów mine. Moreover, an increase in the number of electric cars is associated with an increase in demand for electricity and this, in turn, may translate into an increase in electricity prices [75]. The legislative package called "Fit for 55" (12 directives) adapted by the European Commission on 14 July 2021, which concerns climate protection and the development of energy based on renewable sources, may have a significant impact on the results of respondents' answers. According to the European Union, greenhouse gas emissions are to be reduced by $55 \%$ by 2030 . The "Fit for 55" programme assumes reduction of overall energy consumption, which in turn may have a negative impact on the development of electromobility in the TSL sector. 


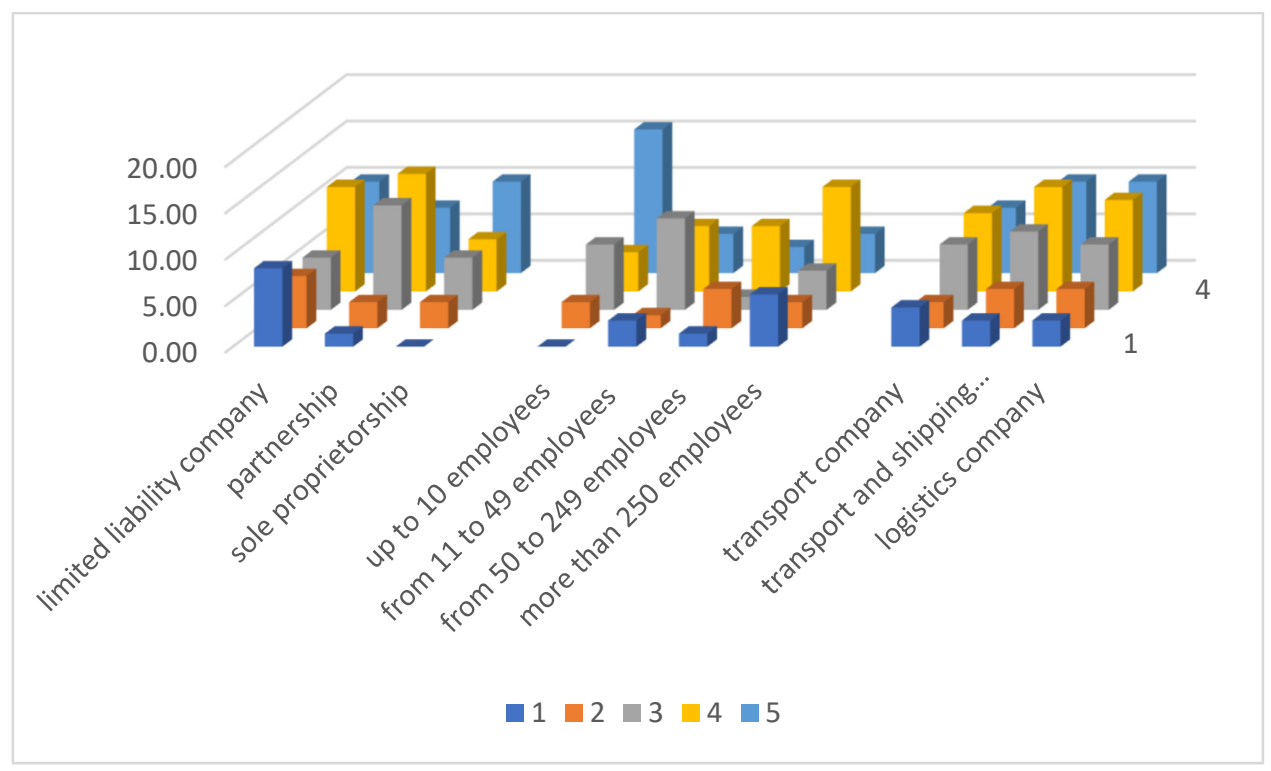

Figure 8. Energy price uncertainty and demand for electric vehicles—criteria organisational and legal form, employment structure, scope of activity.

\section{Discussion}

The COVID-19 pandemic did not directly affect the need to replace the fleet among companies from the TSL sector. The lack of interest was caused by, among other things, the lack of knowledge on electric vehicles among entities from the TSL sector. This was confirmed by the research performed by Higureas-Castillo E. et al. [76] which indicated the poor knowledge of consumers about electric vehicles. Fiscally, most consumers do not know how an electric vehicle works $[77,78]$.

As can be seen from the research carried out, an important aspect that constitutes a barrier to the purchase of electric cars is the availability of charging infrastructure. Research by Raczyński A. et al. [79] indicated that the fundamental issue in electromobility development among TSL companies from the economic point of view is the high cost of purchase and operation of both the vehicles themselves and charging infrastructure. In the case of trucks and delivery vehicles, the most frequently indicated barrier in replacing the conventional fleet with an electric one was the cost of vehicle purchase and the periodic cost of battery replacement, which significantly exceeds the cost of purchasing a traditional fleet vehicle. The same factors affecting the vehicle purchase barrier were confirmed by Durak et al. [80]. They reported that the main barriers to the development of electromobility among heavy-duty vehicles are the high cost of vehicles as a result of high battery prices and the availability of the infrastructure itself, which limits the ability of electric vans or tractor units to move. These conclusions correspond directly with the results of our research, since the availability of charging infrastructure was one of the main factors influencing the purchase of electric vehicles. This was also confirmed by Osiecko K. et al. [81], who pointed out that one of the criteria used to assess the degree of development of electric freight transport in the European Union is the number of charging stations in individual countries. Moreover, the researchers acknowledge that there is a need to expand the infrastructure and plan it in such a way that will allow free transport of goods not only between EU member states.

A problem taken up in the study and referred to in other studies is the issue of electricity price volatility. This factor was important for the surveyed companies. Full electrification of the Polish automotive industry in its current state would require at least 45 billion kWh of additional supply per year. Given the problems with the Turów mine and the Fit for 55 package, the issue of electricity prices and their impact on electromobility requires additional research because of a research gap in this area. Changing socio-economic 
conditions provide a different perspective on the energy sector and the transport sector. The COVID-19 pandemic should motivate us to take on an approach [82] based on a long-term, sustainable perspective, and reinforce the importance of energy security by exploiting the benefits of greater enforcement of sustainable fuels (including truly sustainable-renewableelectric transport). The post-pandemic restart should provide an opportunity to steer the energy system towards more resilient, secure, competitive, and sustainable models.

The post-COVID-19 period should be strongly seized, as it is an unprecedented opportunity to boost transport towards decarbonisation while supporting EU economic activity.

The study shows that the economic situation in the country during the COVID-19 pandemic period had no impact on the development of electromobility in the TSL sector. As indicated by Świtała M. and Łukasiewicz A. [83], despite the slowdown in the economy in most cases, carriers did not reduce their rolling stock and workforce. The results of the research indicated that the prevailing belief was that the drastic fall in demand would be temporary rather than permanent, which turned out to be quite an accurate assumption.

The research results obtained may contribute to deeper research on the development of electromobility in the TSL sector in the context of changes in road transport and the energy sector.

\section{Conclusions, Limitations and Suggestions for Future Research}

Many publications on the impact of the COVID-19 pandemic point to its negative consequences [24,84-86]. However, it is possible to identify areas of socio-economic activity where, under the influence of the COVID-19 pandemic, one can see the absence of negative consequences or notice positive aspects. Based on the collected research material and analyses made on its basis, it can be noted that:

- Diesel-powered vehicles dominate among companies in the TSL sector. Electric vehicles constitute a small percentage of all vehicles. Their number in the general structure of trucks increased despite the COVID-19 pandemic. An important aspect related to the development of electric vehicles is conducting research projects with the participation of companies from the TSL sector.

- The number of publicly available charging points has not changed. The increase was significant especially in 2020. However, the number of charging points from the point of view of TSL companies is insufficient. For this group of vehicle users, fast charging points on motorways and expressways are the most important.

- In the studied group of entities, few entrepreneurs had electric vehicles and few were interested in purchasing them. Taking into account the scope of operations, undoubtedly, companies carrying out international transport must take into account the legal regulations in other countries on limiting $\mathrm{CO}_{2}$ emissions. Moreover, companies operating on the market for more than 10 years may plan to replace their fleet with new vehicles adapted to meet the restrictive requirements. Lack of interest in electric vehicles among the surveyed entrepreneurs results from, among other things, low levels of knowledge of electromobility and lack of awareness of the benefits of electric vehicles or incentive systems for their purchase.

- An important factor which influences the decision not to purchase electric vehicles is the still insufficient number of charging points, including fast charging points. Taking into account the fact that Polish carriers carry out transport all over Europe, the lack of availability of charging infrastructure is a significant argument discouraging companies from replacing their fleets of vehicles.

- Of great importance for TSL sector entities is the situation in the energy sector, including instability of electricity prices. Entrepreneurs point to two important issues that concern the energy sector. On one hand, Fit for 55, which will affect costs in the energy sector, which may be partly transferred to the transport sector, and on the other hand, the issues of decarbonisation, or problems related to incurring penalties by Poland for coal mining in the Turów mine, 
- $\quad$ The economic situation of the country, compared with the development of charging infrastructure and uncertainty of energy prices, was not so important for the surveyed companies in the period of the COVID-19 pandemic. As can be seen, the period of the COVID-19 pandemic even influenced its development thanks to the increase in online shopping, which affected mainly small entrepreneurs delivering in agglomerations. Nevertheless, the share of electric vehicles in the fleets of Polish companies increased only slightly during this period.

To sum up, we may say that the COVID-19 pandemic had no direct impact on the development of electromobility both in Poland and among the surveyed companies. Despite the fact that the surveyed entities constituted a small fraction of the entire sector, citing other studies, they exhibited behaviours similar to those shown by more than $51 \%$ of companies in the TSL sector [14].

Some limitations were encountered in the implementation of the study. One of them was the low participation of companies with electric vehicles. The study could be repeated only in a group of transport companies increasing their number accordingly. It would also be possible to conduct research on the impact of the energy sector on transport companies in the context of electricity affordability and charging infrastructure. Research related to development of electromobility among business entities could also include other groups of actual and potential users of electric vehicles and be conducted among such entities as taxi companies, courier companies, and entities owning fleets of vehicles intended for their own needs (used by sales representatives). On their basis, it would be possible to create a multi-criteria assessment of the possibility of electromobility development during the COVID-19 pandemic or take into account other factors influencing the development of electromobility in road freight transport.

Author Contributions: Conceptualization, T.G.-H. and J.F.; collection of data, J.F.; formal analysis, T.G.-H.; proofing, T.G.-H. and J.F.; methodology, T.G.-H. and J.F.; visualization, T.G.-H.; writingoriginal draft, J.F.; writing-review and editing, T.G.-H. All authors have read and agreed to the published version of the manuscript.

Funding: This research received no external funding.

Institutional Review Board Statement: Not applicable.

Informed Consent Statement: Not applicable.

Conflicts of Interest: The authors report no conflict of interest.

\section{References}

1. Sektor Elektromobilności w Niemczech, Raport Sektorowy; Polska Agencja Inwestycji i Handlu: Warsaw, Poland, 2018.

2. Płachciak, A. Origin of the Idea of Sustainable Development. Economics 2011, 5, 231-248.

3. Brożyna, A.; Kozioł, W. Prognozy wyczerpywania bazy zasobów kopalin-teoria i praktyka. Przegląd Górniczy 2014,4 , 86-89.

4. Smil, V. Energy In The Twentieth Century: Resources, Conversions, Costs, Uses, And Consequences. Annu. Rev. Energy Environ. 2000, 25, 21-51. [CrossRef]

5. The History of The Electric Car. Department of Energy. 15 September 2004. Available online: https://www.energy.gov/articles/ history-electric-car (accessed on 28 January 2022).

6. Grauers, A.; Sarasini, S.; Karlström, M. Why Electromobility and What Is It? In System Perspectives on Electromobility 2013; Sandén, B., Ed.; Chalmers University of Technology: Göteborg, Sweden, 2013; pp. 10-21. Available online: https://publications. lib.chalmers.se/records/fulltext/211430/local_211430.pdf (accessed on 14 December 2021).

7. Gajewski, J.; Paprocki, W.; Pieriegud, J. (Eds.) Elektromobilność w Polsce na tle Tendencji Europejskich i Globalnych; Centrum Myśli Strategicznej, CeDeWu: Warsaw, Poland, 2019. Available online: https://fundacjacms.pl/wp-content/uploads/2019/08/ elektromob_internet.pdf (accessed on 14 December 2021).

8. Kowalski, D.J.; Depta, A. Sustainable Development in Electromobility; Zeszyty Naukowe Politechniki Łódzkiej nr 1228, Organizacja i Zarządzanie z 73; Wydawnictwo Politechniki Łódzkiej: Łódź, Poland, 2019; pp. 69-78. [CrossRef]

9. Energy, Transport and Environment Statistic, Eurostat 2020. Available online: https:/ / ec.europa.eu/eurostat/web/productsstatistical-books/- / KS-DK-20-001 (accessed on 14 December 2021).

10. European Environment Agency. $\mathrm{CO}_{2}$ Performance of New Passenger Cars in Europe. Available online: https://www.eea.europa. eu/ims/co2-performance-of-new-passenger (accessed on 14 December 2021). 
11. Global EV Outlook 2021, Accelerating Ambitions Despite the Pandemic. 2021. Available online: https:/ /iea.blob.core.windows. net/assets / ed5f4484-f556-4110-8c5c-4ede8bcba637/GlobalEVOutlook2021.pdf (accessed on 14 December 2021).

12. Global EV Outlook 2020, Entering the Decade of Electric Drive? 2020. Available online: https://www.iea.org/reports/global-evoutlook-2020.pdf (accessed on 14 December 2021).

13. Floty Samochodów Kluczem do Elektromobilności. Podsumowanie Stanu i Potencjału Rozwoju Rynku Samochodów Elektrycznych w Polsce Oraz Podejście msp do Elektromobilności. PKO Leasing, Czerwiec 2020. Available online: https: / / masterlease. pl/wp-content/uploads/2021-06-floty-samochodow-kluczem-do-elektromobilnosci-raport.pdf (accessed on 14 December 2021).

14. Plan Rozwoju Elektromobilności w Polsce, Ministerstwo Energii, Warszawa, Wrzesień 2016. Available online: https://www. teraz-srodowisko.pl/media/pdf/aktualnosci/2580-Plan-Rozwoju-Elektromobilnosci.pdf (accessed on 14 December 2021).

15. Stark, A. (Ed.) Analysis of Electromobility in Six Countries-Where to Invest Next. Available online: https://www.spotlightmetal. com/analysis-of-electromobility-in-six-countries-where-to-invest-next-a-718387/ (accessed on 14 December 2021).

16. Jaworski, J. Electromobility development in selected European countries in the light of available tax concessions. Eur. J. Serv. Manag. 2018, 28, 187-192. [CrossRef]

17. Auvinen, H.; Jarvi, T.; Kloetzke, M.; Kugler, U.; Bühe, J.A.; Heinl, F.; Kurte, J.; Esser, K. Electromobility scenarios: Research findings to inform policy. Transp. Res. Procedia 2016, 14, 2564-2573. [CrossRef]

18. European Vehicle Market Statistics, Pocketbook 2020/21, icct. 2020. Available online: http:/ / eupocketbook.org/wp-content/ uploads/2020/12/ICCT_Pocketbook_2020_Web.pdf (accessed on 14 December 2021).

19. Regulation (Eu) 2019/1242 Of The European Parliament And Of The Council of 20 June 2019 Setting CO2 Emission Performance Standards for New Heavy-Duty Vehicles and Amending Regulations (EC) No 595/2009 and (EU) 2018/956 of the European Parliament and of the Council and Council Directive 96/53/EC. L 198/202. Available online: http:/ / data.europa.eu/eli/reg/20 19/1242/ oj (accessed on 14 November 2021).

20. Napędzamy Polską Przyszłość. Perspektywy Elektryfikacji Samochodów Dostawczych i Ciężarowych w Polsce, Fundacja Promocji Pojazdów Elektrycznych, Warszawa, Październik 2021. Available online: https://chronmyklimat.pl/media/espada/ filesupload/articles/files-1326/perspektywy-elektryfikacji-samochodow-ciezarowych-i-dostawczych-w-polsce.pdf (accessed on 14 December 2021).

21. Wells, P. Sustainable business models and the automotive industry: A commentary. IIMB Manag. Rev. 2013, 25, 228-239. [CrossRef]

22. Gersdorf, T.; Hensley, R.; Hertzke, P.; Schaufuss, P. Electric Mobility after the Crisis: Why an Auto Slowdown Wan't Hurt EU Demand. 16 September 2020. Available online: https:/ /www.mckinsey.com/industries/automotive-and-assembly/our-insights / electric-mobility-after-the-crisis-why-an-auto-slowdown-wont-hurt-ev-demand (accessed on 14 November 2021).

23. Lewicki, W.; Drożdż, W.; Wróblewski, P.; Żarna, K. The Road to Electromobility in Poland: Consumer Attitude Assessment. Eur. Res. Stud. J. 2021, 24, 28-39. [CrossRef]

24. Nundy, S.; Ghosh, A.; Mesloub, A.; Albaqawy, G.A.; Alnaim, M.M. Impact of COVID-19 pandemic on socio-economic, energyenvironment and transport sector globally and sustainable development goal (SDG). J. Clean. Prod. 2021, 312, 127705. [CrossRef]

25. Elektromobilność w Polsce i w Europie, Mubi News. Available online: https:/ / mubi.pl/dokumenty/elektromobilnosc-w-polscei-europie.pdf (accessed on 7 October 2021).

26. European Commission. Roadmap to a Single European Transport Area-Towards a Competitive and Resource Efficient Transport System; European Commission: Brussels, Belgium, 2011. Available online: http:/ / eur-lex.europa.eu/LexUriServ/LexUriServ.do?uri= COM:2011:0144:FIN:EN:PDF (accessed on 21 October 2021).

27. Wen, W.; Yang, S.; Zhou, P.; Ga, S.Z. Impacts of COVID-19 on the electric vehicle industry: Evidence from China. Renew. Sustain. Energy Rev. 2021, 144, 111024. [CrossRef]

28. Bal, F.; Vleugel, J. The impact of hybrid engines on fuel consumption and emissions of heavy-duty trucks. WIT Trans. Ecol. Environ. 2017, 224, 203-212. Available online: https://www.witpress.com/Secure/elibrary/papers/ESUS17/ESUS17019FU1.pdf (accessed on 14 December 2021).

29. Ghandriz, T.; Jacobson, B.; Laine, L.; Hellgren, J. Impact of automated driving systems on road freight transport and electrified propulsion of heavy vehicles. Transp. Res. Part C 2020, 115, 102610. [CrossRef]

30. Vehicles in Use Europe 2022, acea, Jaunary 2022. Available online: https:/ / www.acea.auto/files / ACEA-report-vehicles-in-useeurope-2022.pdf (accessed on 14 December 2021).

31. Jak COVID-19 Wpłynie na Rozwój Samochodów Elektrycznych i Autonomicznych. 2020. Available online: https:/ /knaufautomotive. $\mathrm{com} / \mathrm{pl} /$ jak-covid-19-wplynie-na-rozwoj-samochodow-elektrycznych-i-autonomicznych/ (accessed on 14 December 2021).

32. Membrillo-Hernández, J.; Lara-Prieto, V.; Caratozzolo, P. Sustainability: A Public Policy, a Concept, or a Competence? Efforts on the Implementation of Sustainability as a Transversal Competence throughout Higher Education Programs. Sustainability 2021, 13, 13989. [CrossRef]

33. Report of the World Commission on Environment and Development Our Common Future. ONZ 1987, 10, 1-300.

34. Siemiński, J.L. Idea "Rozwoju Zrównoważonego i Trwałego" Obszarów Wiejskich w Polsce na tle Innych Koncepcji. Ujęcie Planistyczne (Część I); Infrastruktura i Ekologia Terenów Wiejskich: Kraków, Poland, 2008; Volume 2, pp. 7-20. Available online: http:/ /www.infraeco. $\mathrm{pl} / \mathrm{pl} / \mathrm{art} / \mathrm{a} \_15178 . h \mathrm{tm}$ (accessed on 14 December 2021). 
35. James, P. Urban Sustainability in Theory and Practice: Circles of Sustainability; Routledge: London, UK, 2014. Available online: https:/ / www.taylorfrancis.com/books/mono/10.4324/9781315765747/urban-sustainability-theory-practice-paul-james (accessed on 14 December 2021).

36. Burchard-Dziubińska, M.; Rzeńca, A.; Drzazga, D. Zrównoważony Rozwój-Naturalny Wybór; Wydawnictwo Uniwersytetu Łódzkiego: Łódź, Poland, 2014.

37. Litman, T.; Burwell, D. Issues in Sustainable Transportation. Int. J. Glob. Environ. Issues 2006, 6, 331-347. Available online: https://www.vtpi.org/sus_iss.pdf (accessed on 14 December 2021). [CrossRef]

38. Motowidlak, U. Rozwój transport a paradygmat zrównoważonego rozwoju, Studia Ekonomiczne. Zesz. Nauk. Uniw. Ekon. W Katowicach 2017, 337, 138-152. Available online: https:/ /www.ue.katowice.pl/fileadmin/user_upload/wydawnictwo/SE_ Artyku\%C5\%82y_321_340/SE_337/10.pdf (accessed on 14 December 2021).

39. Borys, T. Pomiar zrównoważonego rozwoju transportu. In Ekologiczne Problemy Zrównoważonego Rozwoju; Kiełczewski, D., Dobrzyńska, B., Eds.; Wyższej Szkoły Ekonomicznej w Białymstoku: Białystok, Poland, 2009.

40. Schaumann, H. Development of a Concept for Inner-City Delivery \& Supply Utilising Electromobility. In Efficiency and Logistics; Clausen, U., Hompel, M., Klumpp, M., Eds.; Springer-Verlag: Berlin, Germany, 2013; pp. 121-127.

41. Scheffels, G.; Alexander Stark, A. Electromobility: Definition, Vehicles and Future. Available online: https://www.spotlightmetal com/electromobility-definition-vehicles-and-future-a-810482/ (accessed on 14 December 2021).

42. Caternì, A.; Cascetta, E.; Luca, S. A random utility model for park \& carsharing services and the pure preference for electric vehicles. Transp. Policy 2016, 48, 49-59. [CrossRef]

43. Lara, F.F.; Marx, R. Comparative positioning between Brazilian subsidiaries and Europeanmatrices on Electromobility and carsharing technologies. Res. Transp. Bus. Manag. 2018, 27, 67-74. [CrossRef]

44. Ceschin, F.; Vezzoli, C. The role of public policy in stimulating radical environmental impact reduction in the automotive sector: The need to focus on product-service system innovation. Int. J. Automot. Technol. Manag. 2010, 10, 321-341. [CrossRef]

45. MacDougall, W. Electromobility in Germany: Vision 2020 and Beyond; German Trade \& Invest Issue: Bonn, Germany, 2013.

46. Elektromobilność, Polskie Stowarzyszenie Elektromobilności. Available online: http://www.psem.pl/elektromobilnosc.html (accessed on 14 November 2021).

47. Osorio-Tejada, J.; Llera, E.; Scarpellini, S. LNG: An Alternative Fuel For Road Freight Transport In Europe. WIT Press 2015, 168, 235-246. [CrossRef]

48. Navas-Anguita, Z.; Garcia-Gusano, D.; Irbarren, D. A review of techno-economic data for road transportation fuels. Renew. Sustain. Energy Rev. 2019, 112, 11-26. [CrossRef]

49. Muratori, M.; Smith, S.J.; Kyle, P.; Link, R.; Mignone, B.; Kheshgi, H. Role of the Freight Sector in Future Climate Change Mitigation Scenarios. Environ. Sci. Technol. 2017, 51, 3526-3533. [CrossRef] [PubMed]

50. Wang, Z.; Ahmen, Z.; Zhang, B.; Wang, B. The nexus between urbanization, road infrastructure, and transport energy demand: Empirical evidence from Pakistan. Environ. Sci. Pollut. Res. 2019, 26, 34884-34895. [CrossRef] [PubMed]

51. Cantarero, M.M.V. Decarbonizing the transport sector: The promethean responsibility of Nicaragua. J. Environ. Manag. 2019, 245, 311-321. [CrossRef] [PubMed]

52. Skrứcańy, T.; Kendra, M.; Stopla, O.; Milojević, S.; Figlus, T.; Csiszăr, C. Impact of the Electric Mobility Implementation on the Greenhouse Gases Production in Central European Countries. Sustainability 2019, 11, 4948. [CrossRef]

53. Helgeson, B.; Peter, J. The role of electricity in decarbonizing European road transport-Development and assessment of an integrated multi-sectoral model. Appl. Energy 2020, 262, 114365. [CrossRef]

54. Quak, H.; Nesterova, N.; Roijen, T.; Dong, Y. Zero emission city logistics: Current practices in freight electromobility and feasibility in the near future. Transp. Res. Procedia 2016, 14, 1506-1515. [CrossRef]

55. Geronikolos, I.; Potoglou, D. An exploration of electric-car mobility in Greece: A stakeholders' perspective. Case Stud. Transp. Policy 2021, 9, 906-912. [CrossRef]

56. Vehicles in Use Europe 2021, Acea. Jaunary 2021. Available online: https:/ /www.acea.auto/files / report-vehicles-in-use-europejanuary-2021-1.pdf (accessed on 14 December 2021).

57. Połom, M. E-revolution in post-communist country? A critical review of electric public transport development in Poland. Energy Res. Soc. Sci. 2021, 80, 102227. [CrossRef]

58. Transport Wyniki Działalności w 2017 r; GUS: Warsaw, Poland, 2018.

59. Transport Wyniki Działalności w 2018 r; GUS: Warsaw, Poland, 2019.

60. Transport Wyniki Działalności w 2019 r; GUS: Warsaw, Poland, 2020.

61. Transport Wyniki Działalności w 2020 r; GUS: Warsaw, Poland, 2021.

62. Gryz, J.; Podraza, A.; Ruszel, M. Bezpieczeństwo Energetyczne. Koncepcje, Wyzwania, Interesy; PWE: Warsaw, Poland, 2018.

63. Strategia na Rzecz Odpowiedzialnego Rozwoju do Roku 2020 (z Perspektywa do Roku 2030 r); Dokument Przyjęty Uchwała Rady Ministrów w Dniu 14 Lutego 2017 r; Rady Ministrów: Warsaw, Poland, 2017.

64. Barometr Nowej Mobilności 2020/2021; PESA: Warsaw, Poland, 2020.

65. Licznik Elektromobilności, Sierpień 2021. Available online: https://pspa.com.pl/wp-content/uploads/2021/09/licznik_ elektromobilnosci_2021-08_A4_PL.jpg (accessed on 18 November 2021).

66. E-taryfa. Nowa Energia dla Elektromobilności; Ministerstwo Klimatu i Środowiska: Warsaw, Poland, 2020.

67. Drożdż, W. The development of electromobility in Poland. Virtual Econ. 2019, 2, 61-69. [CrossRef] 
68. Pagany, R.; Camargo, L.; Dorner, W. A review of spatial localization methodologies for the electric vehicle charging infrastructure. Int. J. Sustain. Transp. 2019, 13, 433-449. [CrossRef]

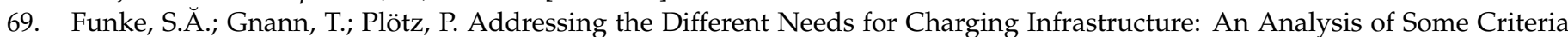
for Charging Infrastructure Set-up. In E-Mobility in Europe; Filho, W.L., Kotter, R., Eds.; Trends and Good Practice; Springer: Berlin/Heidelberg, Germany, 2015; pp. 73-90. [CrossRef]

70. Matejun, M. Metodyka badań ankietowych w naukach o zarządzaniu-ujęcie modelowe. In Wspótczesne Problemy Rozwoju Metodologii Zarządzania; Lisiński, M., Ziębicki, B., Eds.; Fundacja Uniwersytetu Ekonomicznego w Krakowie: Kraków, Poland, 2016; pp. 341-354.

71. Harpe, S.E. How to analyze Likert and other rating scale data. Curr. Pharm. Teach. Learn. 2015, 7, 836-850. [CrossRef]

72. Chen, Y.-P. Do the Chi-Square Test and Fisher's Exact Test Agree in Determining Extreme for $2 \times 2$ Tables? Am. Stat. 2011, 64, 239-245. [CrossRef]

73. Miesięczny Indeks Koniunktury, Polski Instytut Ekonomiczny, Październik 2021. Available online: https://pie.net.pl/wpcontent/uploads/2021/10/MIK_10-2021.pdf (accessed on 18 November 2021).

74. Senderek-Matysiak, E.; Łosiewicz, Z. Analysis of the Development of the Electromobility Market in Poland in the Context of the Implemented Subsidies. Energies 2021, 14, 222. [CrossRef]

75. Wagner, M.; Schönsteiner, K.; Hamacher, T. Impacts of Photovoltaics and Electromobilityon the Singaporean Energy Sector. Energy Procedia 2012, 25, 126-134. [CrossRef]

76. Higureas-Castillo, E.; Liébana-Cabanillas, F.J.; Muñoz-Leira, F.; García-Maroto, I. Evaluating consumer attitudes toward electromobility and the moderating effect of perceived consumer effectiveness. J. Retail. Cust. Serv. 2019, 51, 387-398. [CrossRef]

77. Anable, J.; Lane, B.; Keley, T. An Evidence Base Review of Public Attitudes to Climate Change and Transport Behaviour; The Department for Transport: Warsaw, Poland, 2006.

78. Krause, R.M.; Carley, S.R.; Lane, B.W.; Graham, J.D. Perception and reality: Public knowledge of plug-in electric vehicles in 21 U.S. cities. Energy Policy 2013, 63, 433-440. [CrossRef]

79. Raczyński, A.; Malinowska, M.; Pokorska, A. Analiza uwarunkowań rozwoju elektromobilności w przewozie ładunków. Probl. Transp. I Logistyki 2018, 12, 73-84.

80. Dulak, M.; Musiałek, P. (Eds.) Z Prądem czy pod Prąd? Perspektywy Rozwoju Elektromobilności w Polsce; Klub Jagielloński: Kraków, Poland, 2018.

81. Osiecko, K.; Zimon, D.; Płaczek, E.; Prokopiuk, J. Factors that influence the expansion of electric delivery vehicles and trucks in EU countries. J. Environ. Manag. 2021, 296, 113177. [CrossRef]

82. Chiaramonti, D.; Maniatris, K. Security of supply, strategic storage and COVID19: Which lessons learnt for renewable and recycled carbon fuels, and their future role in decarbonizing transport? Appl. Energy 2020, 271, 115216. [CrossRef]

83. Świtała, M.; Łukasiewicz, A. Road Freight Transport Companies Facing The COVID-19 Pandemic. Gospod. Mater. Logistyka 2021, 5, 8-16. [CrossRef]

84. Qiu, W.; Rutherford, S.; Mao, A.; Chu, C. The Pandemic and its Impacts. Health Cult. Soc. 2017, 9-10, 3-11. [CrossRef]

85. Seberini, A.; Tokovska, M. Impact of the COVID-19 Pandemic on Changing the Content of Social Media Advertising. Studio Ecol. Bioethicae 2021, 19, 61-71. [CrossRef]

86. Krajewski, M.; Fraczkowik, M.; Kubacka, M.; Rogowski, Ł. The bright side of the crisis. The positive aspects of the COVID-19 pandemic according to the Poles. Eur. Soc. 2020, 23, S777-S790. [CrossRef] 